\title{
Exploring of Student's Algebraic Thinking Process Through Pattern Generalization using Similarity or Proximity Perception
}

\author{
Iva Nurmawanti ${ }^{*}$ and I Made Sulandra ${ }^{2}$ \\ ${ }^{1 *}$ Program Studi Pendidikan Matematika, Universitas Mataram \\ Jalan Majapahit No. 62, Gomong, Selaparang, Mataram, NTB, Indonesia \\ 1*ivanurmawanti@unram.ac.id \\ ${ }^{2}$ Program Studi Pendidikan Matematika, Universitas Negeri Malang \\ Jalan Semarang No. 5, Sumbersari, Lowokwaru, Malang, Jawa Timur, Indonesia \\ 2made.sulandra.fmipa@um.ac.id
}

Artikel diterima: 24-10-2019, direvisi: 11-04-2020, diterbitkan: 31-05-2020

\begin{abstract}
Students' algebraic thinking skills must continue to be developed because they can support success in mathematics. Algebraic thinking relates to generalizing patterns learned at the junior secondary level. During the process of generalizing students use the perception of similarity or proximity. Therefore, the purpose of this study is to describe the algebraic thinking process of junior high school students in generalizing patterns. The approach used is qualitative with 3 research subjects who have different algebraic thought processes. The results showed that junior high school students carried out algebraic thought processes by perceiving images, representing, looking for functional relationships, making generalizations, and applying general formulas. The difference in perception is used early in the activity and in the search for functional relationships. The results of this study can be used in developing mathematics learning strategies so that students' algebraic thinking skills develop.

Keyword: algebraic thinking, pattern identification, pattern generalization, perception of proximity, perception of similarity.
\end{abstract}

\section{Eksplorasi Proses Berpikir Aljabar Siswa Melalui Generalisasi Pola yang Menggunakan}

\section{Persepsi Similarity atau Proximity}

\begin{abstract}
Abstrak
Kemampuan berpikir aljabar siswa harus terus dikembangkan karena dapat mendukung kesuksesan dalam matematika. Berpikir aljabar generalisasi dengan generalisasi pola yang dipelajari pada tingkat SMP. Pada saat proses melakukan generalisasi siswa menggunakan persepsi similarity atau proximity. Oleh sebab itu, tujuan penelitian ini yaitu mendeskripsikan proses berpikir aljabar siswa SMP dalam melakukan generalisasi pola. Pendekatan yang digunakan yaitu kualitatif dengan 3 subjek penelitian yang memiliki proses berpikir aljabar yang berbeda. Hasil penelitian menunjukkan bahwa siswa SMP melakukan proses berpikir aljabar dengan mempersepsikan gambar, merepresentasikan, mencari hubungan fungsional, melakukan generalisasi, dan mengaplikasikan rumus umum. Perbedaannya persepsi digunakan di awal kegiatan dan pada kegiatan pencarian hubungan fungsional. Hasil penelitian ini dapat digunakan dalam mengembangkan strategi pembelajaran matematika agar kemampuan berpikir aljabar siswa berkembang.

Kata Kunci: identifikasi pola, generalisasi pola, pemikiran aljabar, persepsi proximity, persepsi similarity.
\end{abstract}




\section{INTRODUCTION}

The ability to think algebra must be possessed by every student to successfully learn mathematics. This is because most of the mathematical material is closely related to algebra. Generally, algebra is defined as symbol manipulation, while thinking algebra about generalization (Girit \& Akyuz, 2016). The use of algebraic symbols at the initial level is needed as a tool in the process of analyzing relationships between quantities, identifying structures, identifying regular quantity changes, making generalizations, solving problems, making models, and predicting lots of quantities in subsequent pattern sequences (Kieran, 2004).

Lian \& Yew, (2012) explained that there are steps taken by algebraic thinking to solve generalization problems. The steps are: (1) finding and understanding data from existing problems; (2) represent information mathematically using words, tables, graphs; (3) generalizing patterns in the form of equations; (4) explain and apply solutions to solve problems, test suspicions, and identify functional relationships, in the same situation, new, or related. Furthermore, the development of the ability to teach can be done by (1) building a series of new perceptions and actions based on specific objectives, (2) adapting to more formal mathematical activities, (3) building a way that is in accordance with the perceptions and actions that we build cognitively to improve
2017). the ability to think algebra must get attention in school. However, at present, assignments, exercises or problems to explore and develop generalizations are rarely given (Ayber \& Tanışlı, 2017; Ridia \& Afriansyah, 2019). According to Warren \& Cooper (2007), many high school students also have difficulty relating to investigating figural patterns, understanding patterns as functional relationships and abilities in algebra.

Based on the above, many kinds of research on patterns are carried out, one of which is related to figural patterns. Based on (Lie, Zhi, \& Sean's, 2017) research assignments about figural patterns can lead to figural and numerical strategies. Whereas assigning assignments about numerical patterns only brings up numerical strategies. The development and improvement of problem-solving abilities, algebraic thinking, and understanding of geometrical and spatial relationships can be developed by giving the task of the generation of figural patterns (Kılıç, 2016; Mulyani, Indah, \& Satria, 2018). Tasks about figural patterns can also develop abilities in making algebraic formulas (Kılıç, 2017). Students' mathematical abilities and creativity can also be increased by assigning figural patterns (Vale, Pimentel, Cabrita, \& Barbosa, 2012). Dundar (2015) found facts by multiplying exercises to find relationships that exist in patterns and
The importance of generalization and 
making generalizations can make students able to understand problems in real life (Faturohman \& Afriansyah, 2020).

Patterns in mathematics can be described as rules of a series of mathematical objects (Guerrero \& Rivera, 2002). These mathematical objects usually involve numbers or geometric shapes (Mulligan, Mitchelmore, Kemp, and Marston 2008: 10). Patterns are an important part of mathematics because many of the basic principles of school mathematics are built from generalizing patterns to numbers (Zazkis and Liljedahl, 2002; Fyfe, et.al, 2017). Therefore, starting from the basic level the tasks that have to do with patterns are often given. Task about patterns at the primary level can contribute to the development of problemsolving abilities, the ability to analyze cases, organize data systematically, make justifications and generalizations (Barbosa, et al, 2007).

Generalization plays an important role in learning mathematics widely and exists in many topics (Chua \& Hoyles, 2014; Afriansyah, et al., 2019). One topic that is closely related to generalization is about patterns. According to (Barbosa \& Vale, 2015) when students explore patterns, they find relationships between elements of the pattern according to their position, using generalizations to find many objects in other positions. So students are not focused on variables but they are looking for functional relationships. This is consistent with explanation of (Wilkie,
2019) that giving assignments about figural patterns is given as an initial route to develop students' abilities about functional relationships (Wilkie, 2019). The ability to understand functional relationships or functional thinking has a major role in algebraic thinking (Somasundram, Akmar, \& Eu, 2019).

The development of algebraic thinking skills can also be done by giving assignments about pattern generalization (Chua \& Hoyles, 2014). Learning to discover, explain, translate and expand patterns is part of working on math and algebraic thinking (Walle, et al 2009: 259). Initially, algebraic thinking only involved the introduction of general mathematical patterns and relationships between numbers, objects and geometric shapes (Windsor, 2009). Furthermore, observations about number patterns that can underlie generalization activities and express them in words, diagrams, and symbols are also algebraic thinking (Papic, et.al 2011).

The process of finding relationships in patterns is an identification process. To find these relationships students observe pattern characteristics (Barbosa \& Vale, 2015). In figural patterns, observations are made by looking at the constituent patterns of patterns which are then interpreted by students into certain forms. The results of these interpretations are used to look for relationships between images in figural patterns. Next students observe the relationship between each 
part of the pattern based on its position. According to (Radford, 2015), the way students see components in patterns is an example of perception. This is supported by research conducted by (Nurmawanti; Bambang; \& Sulandra, 2016) that when students identify student patterns using their perceptions. The perceptions used to identify patterns are the laws of proximity, similarity, closure, and continuity. Based on these studies it can be identified that there is a relationship between perception and students' algebraic thinking processes, especially those who use similarity or proximity perceptions in generalizing patterns. Research on the algebraic thinking process and pattern is mostly done by researchers (Kieran, 2004; Girit \& Akyuz, 2016; \& Maryati, 2018), but none of them related to student's perception. Therefore, this study aims to describe the algebraic thinking process of students who use the perception of similarity and proximity when generalizing patterns.

\section{MethOD}

This research will describe the students' algebraic thought processes that use the perception of similarity and proximity in generalizing patterns. To find out the description, a qualitative approach is carried out by finding and analyzing data. A qualitative approach is used to get detailed information about students' algebraic thinking processes.

Subjects in this study were taken from 25 middle-class students. The process of determining the research subject uses purposive sampling. Questions in Picture 1 are given to these students. The instrument has been validated. Furthermore, the data of students' work results are analyzed to determine whether students use generalization strategies using perception or not. Based on the results of the analysis, seven students determined that there were used perception of similarity and proximity in the generalization process based on their written communication. Then the seven students were interviewed to explore more about their work. Based on the analysis results of different communication skills and algebraic thinking processes, three students were selected as research subjects. Furthermore, the selected student subject was asked to do a similar problem. Students are also asked to explain what is thought out loud. Furthermore, the data from the thee subjects were analyzed to obtain data about the thingking process. If there is insufficient data, it will be extracted from the subject using interviews.

The method of constant comparison is used to analyze research data. The following steps are used: (1) translating data from written work and think out loud, (2) reviewing all available data from various sources, namely from students' written work, think out loud, and interviews (if any), (3) reduce data by making core summaries, procedures, and interview statements that need to be controlled so that they are always consistent, (4) 
constructing units by coding, (5) describing students' algebraic thinking frameworks that use the perception of similarity or proximity in generalizing pattern, and (6) draw conclusions.

\section{Results And Discussion}

Based on data obtained from S1, S2, and S3 will get a description of the algebraic thought process in generalizing patterns. S1 and S3 both use the perception of similarity or proximity. Whereas S2 only uses proximity perception. The questions solved by students are as follows.

Based on the picture below, determine how many dots in the $4^{\text {th }}, 15^{\text {th }}$ of image! Then determine the formula for the $\mathrm{n}^{\text {th }}$ of image!

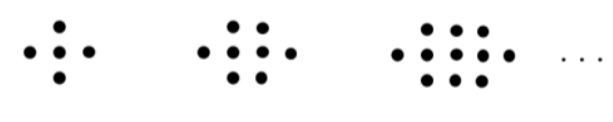

Picture 1. Problem of Generalization Pattern.

Based on the questions in picture 1, students have explored. Exploration is done by students to find as many ways as possible that can be used to solve problems. Therefore, many ways are found by students. S1 found three ways to generalize patterns. The first way uses proximity perception, the second way uses perception of similarity and proximity, while the third way uses perception of similarity. The results of S1 work as follows.

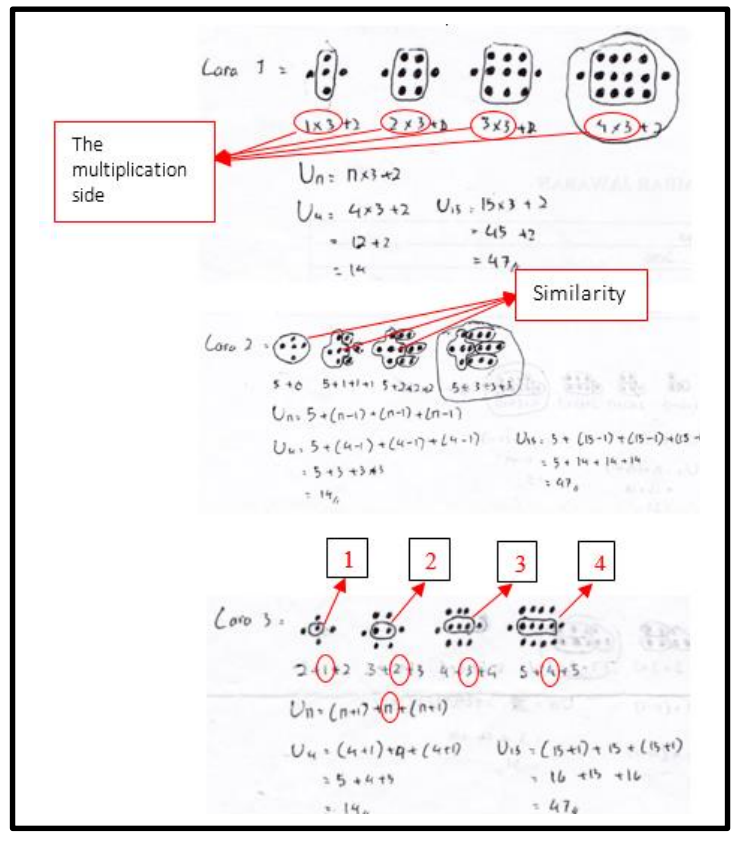

Picture 2. S1's answer

In a first way, images are identified based on their perception. Images are perceived as proximity by producing separate images. Images perceived by S1 into three parts in the middle and on the right and left. The middle part is perceived as a rectangular shape. Furthermore, students develop existing problems by drawing the $4^{\text {th }}$ image which is used to understand the structure of the picture widely. The $4^{\text {th }}$ picture is also perceived as the previous pictures. Furthermore, the number of points in the image are represented numerically. The numerical representation is related to its perception. For the area perceived as a rectangle, the area is calculated by multiplying the edges. For the next step, S1 analyzes the functional relationship between the position of the image and the numerical 
representation. The step that used to see the structure of pattern generalization is an initial activity to understand function (Rivera, 2018).

S1 has understood the functional relationship by looking at the numbers that always change according to the position of the picture. S1 has understood these numbers will continue to grow in accordance with the development of the image. This is used by S1 to make generalizations. Based on the generalizations they have made they can determine the number of dots in the 4th and 15th figures. This is the process of applying the generalization formula to a new situation. This process is also part of algebraic thinking (Lian \& Yew, 2012).

In a second way, S1 has combined the perception of similarity and proximity. When S1 identified the image components, S1 saw the similarities in each picture. To ensure this, S1 has drawn the 4th pattern that related with the previous images. Based on the similarity that has been seen, S1 has seen that there are parts of the image that are not the same and are composed of separate components. The Images viewed separately will always grow and continue. S1 has seen many separate image components related to image position. Indirectly at this step students have used functional thinking. Functional thinking has been carried out along with the process of perceiving images. After that, S1 used the results of identification by numerically representing. Based on numerical representation, S1 has been looking for functional relations to make it easier to find the correct formula. The formula that found by exploring images, looking for relationships between images and numbers are built will be able to facilitate students in understanding variables (Barbosa, Value, \& Palhares, 2009). Generalization formulas that contain variables are applied to determine the number of dots in the next figure.

In a third way, when looking at the structure of image S1 use the perception of closeness. S1 has seen the similarity of the image component in the middle with the image position. In this way, S1 has made the perception of closeness while doing functional thinking. Currently, S1 has justified that when perceiving images can be done together by looking for functional relationships. Furthermore, the justification is proven by making generalizations made in the first and third ways. When a student makes a generalization process he has justified making a general formula and proving it (Ellis, 2007). This process can train students to build algebraic generalization abilities to be able to do mathematical proofs.

When S1 proved the justification, numerical representation was used by $\mathrm{S} 1$ to make the way more easier. In addition to determining numerical representation, S1 also determined the numbers that grow according to the position of the image. Functional thinking has been used again by S1 at this step. Based on the analysis of the 
functional relationship S1 generalizes by general formula is used to determine the determining the general formula. The number of dots in a new problem.

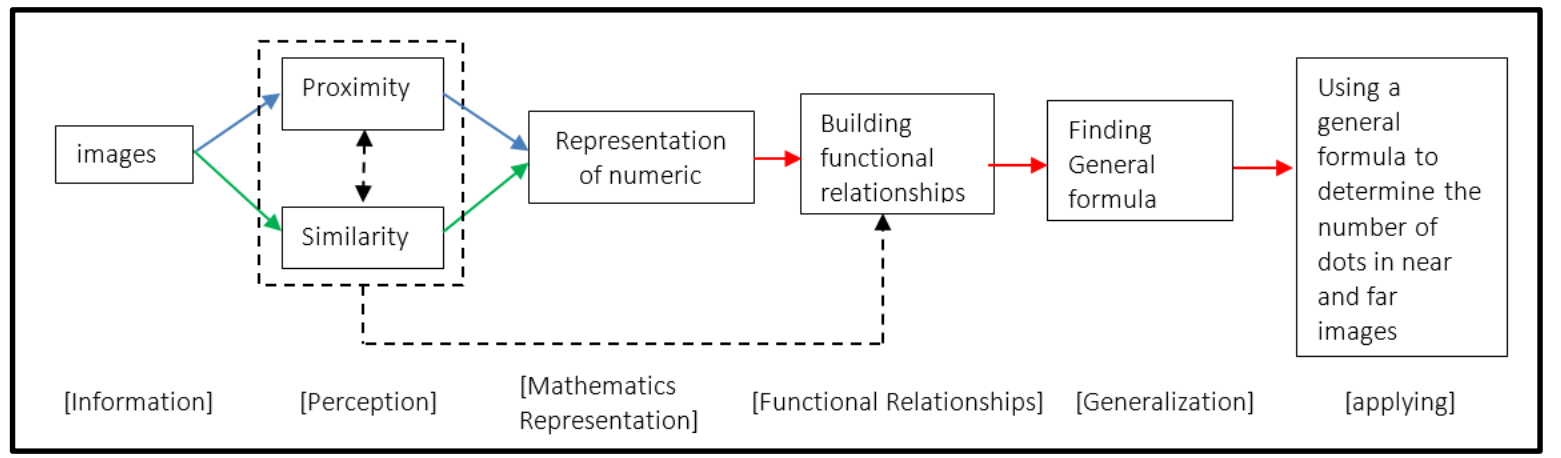

Diagram 1. Algebraic thinking process by S1

S2 generalizes by using proximity perception. the first way S2 perceives images as separate components. 52 has seen the same compiler, which is the middle part arranged by a group of dots. Each group is arranged from 3 points. At each image position, $\mathrm{S} 2$ has seen that the number of groups of dots is the same as the position of the image. This means that at this stage S2 has made a functional relationship. When students practice investigations to find the initial rules, they can help improve thinking skills (Warren, Miller, \& Cooper, 2013). The process of students finding rules can be seen from the following picture.

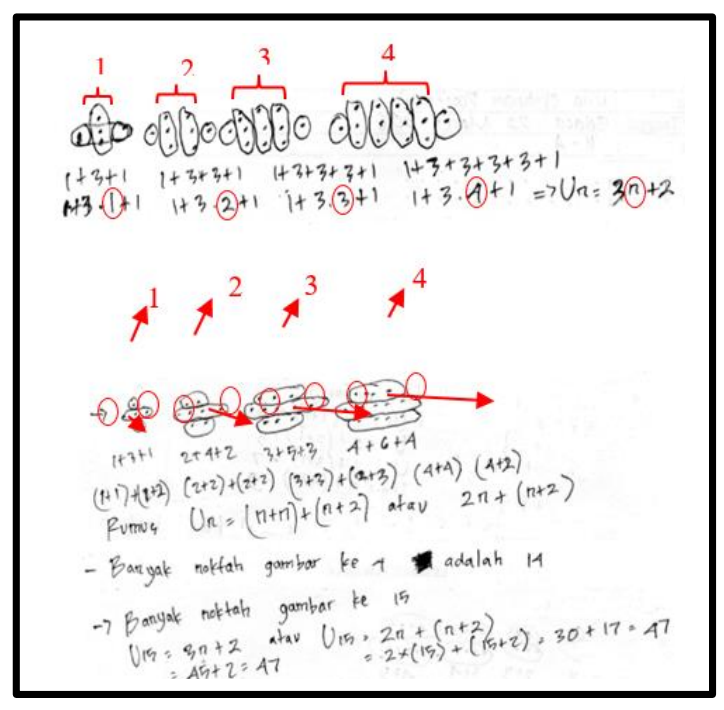

Picture 3. S2's answer

The same way of identification was done S2 in a second way. The way S2 perceived images with proximity laws. It is related to image positions. According to $\mathrm{S} 2$, this makes it easier to make generalizations. Following is S2's explanation in how to identify images by looking for the relationships between image positions at the same time. This in the explanation by $\$ 2$ when $\mathrm{S} 2$ was interviewed. 
R: Explain how did you identify the picture in the first way?

S2: This picture (showing the picture) has parts that are located right and left with the number of dots is 1 . While in the middle there are several parts arranged from parts with the number of dots is 3. In the first image, there is $1 \mathrm{dot}$, the second image there are 2 dots, the third image there are 3 dots, and the fourth image there are 4 dots. This will continue according to the position of the image.

$R$ : What about the second way?

S2: Same as the 1 ma'am?

$R$ : What do you mean?

S2: This image has 3 parts, namely the top, middle, and bottom. This picture, if seen there must be a relationship between these components with the position of the image. The first way is the group in the middle, the top, and bottom ones.

$R$ : Why did you always see the connection?

S2: Because it makes it easier to find the formula. If it is following the position of the image, it will become $n$ in the general formula.
After S2 has identified the image, the results are represented as numbers. Based on the representation made formally the S2 has been looking for functional relations. Numeric operations are used to determine generalizations. Generalizations are made according to identification results. So, with the same problem S1 can determine different formulas. Different formulas can be made by students on the same problem influenced by the way they look at the structure of images or perceptions (Nurmawanti, Bambang, \& Sulandra, 2016). The formula created by $\$ 2$ was only applied to determine the number of 15th image points. While to determine the dot in the 4th image, S2 calculates the identification results.

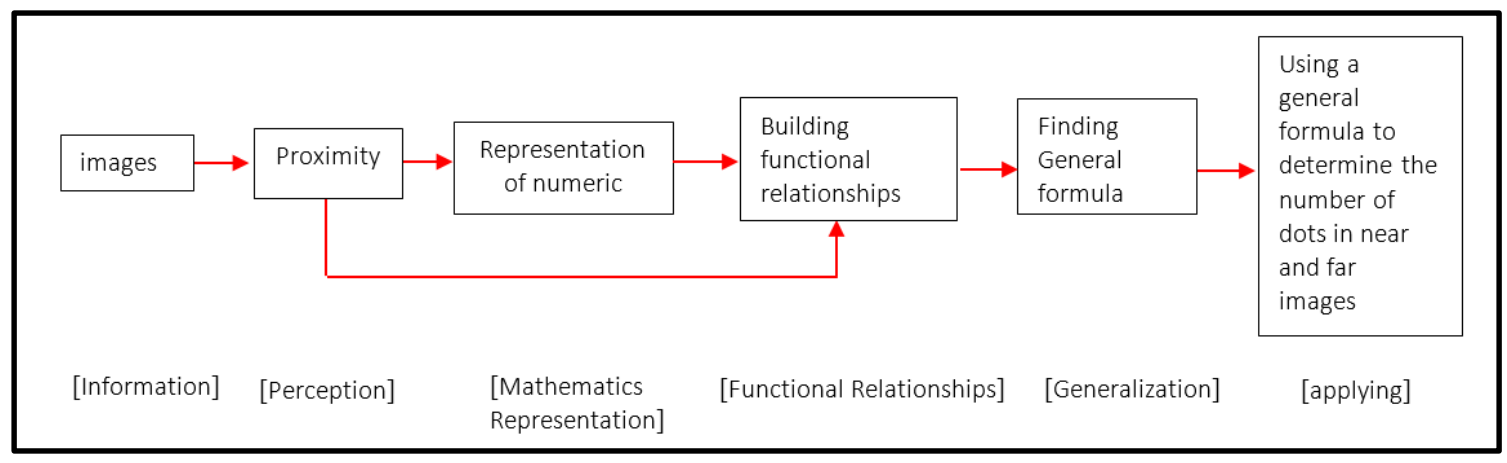

Diagram 2. Algebraic thinking process by S2

S3 specifies two ways to generalize patterns. The first method uses proximity perception. Whereas the second method uses similarity perception.

In the first way, S3 seen three part. There are in the middle, on the right and left. Then based on its perception, S3 made a numerical representation by counting each separate part. Based on these representations S3 looked for functional relationships between numbers and image positions. Based on the functional relationship built by S3, a general formula can be determined. General formulas are made related to perceptions and functional relationships that are built. 


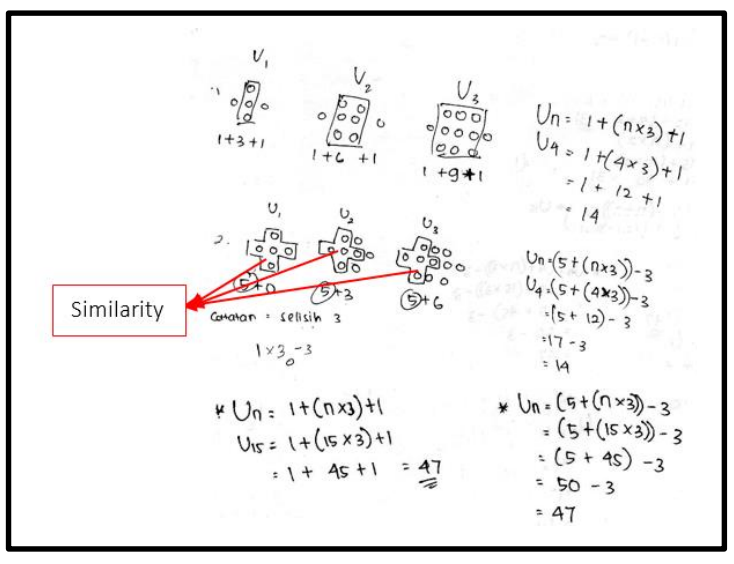

Picture 4. S3's answer

At this stage of identification, S3 did not draw the 4th picture. S3 felt it was enough to identify with only three images. The number of points in the 4th image is found by applying the formula that has been made. It's same to find the 15th image sought by applying the general formula made.

For the second way, the perception of similarity is used by $\mathrm{S3}$ to identify patterns. S3 was seen similarities in each picture. These similarities have the same form and quantity. Furthermore, the remainder of the same section is calculated by the number of points to construct numerical representations. Furthermore, S3 builds a functional relationship on non-fixed numbers. So the general formula can be determined. Like method 1 , the formula used is used S3 to determine the many points in the 4 th and 15 th figures. Using the general formula to determine the many points in the next image is more effective than the recursive event pad. This will make it easier for students because the recursive way is too tiring to determine many points in the distant position of the image (Lannin, Barker, \& Townsend, 2006).

For the second way, the perception of similarity is used by S3 to identify patterns. S3 was seen similarities in each image. These similarities have the same form and quantity. Furthermore, the remainder of the same section is calculated by the number of dots to construct numerical representations. Furthermore, S3 built a functional relationship with non-fixed numbers. So the general formula can be determined. Like in the first way, the formula used is used S3 to determine the number of dots in the $4^{\text {th }}$ and $15^{\text {th }}$ of image. Using the general formula to determine the number of dots in the next image is more effective than the recursive way. This will make it easier for students because the recursive way is too tiring to determine the number of dots far position of the image (Lannin, Barker, \& Townsend, 2006). 


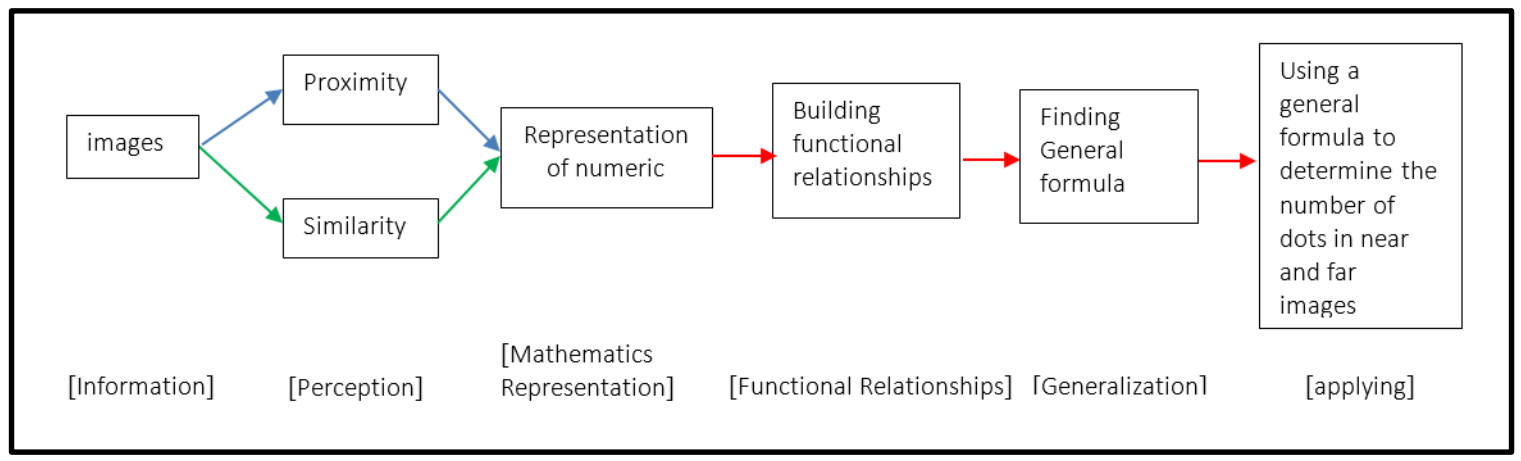

Diagram 3. Algebraic thinking process by S3

\section{CONCLUSION}

The algebraic thought process used by S1, S2, and S3 through five parts. The five sections perceive, represent, look for functional relationships, generalize, and apply general formulas. The process of perceiving an image is used to identify the components of the image. In the process of identification, S1 and S2 perceive images while looking for functional relationships. But S3 did not do this. Functional relationships are built by finding numbers that match the position of the image to find a general formula. General formulas determined by S1, S2, and S3 relate to perceptions and functional relationships that they build. Therefore, the formula made by them is different. They only understood that the formula was the same. But they have not used algebraic operations to simplify the formulas they form. This can be used to develop the concepts of algebraic operations and algebraic equations in early school. The generalization process is done by making a general formula. This formula is used S1 and S3 to determine the many points at the position of the next image far and near. But for S2 the position of the near image is determined by calculating the image component based on the representation it makes. The general formula is only used to specify many points on a distant picture. The result of this research can be used to improve students' algebraic thinking skills using similarity or proximity perceptions.

\section{ACKNOWLEDGMENT}

The high appreciation is given to students at Tulungagung Middle School who were involved in taking this data.

\section{REFERENCES}

Afriansyah, E. A., Puspitasari, N., Luritawaty, I. P., Mardiani, D., \& Sundayana, R. (2019). The analysis of mathematics with ATLAS.ti. Journal of Physics: Conference Series, 1402(7), 077097.

Ayber, G., \& Tanışlı, D. (2017). An analysis of middle school mathematics textbooks from the perspective of fostering algebraic thinking through generalization. Kuram ve Uygulamada Egitim Bilimleri, 17(6), 2001-2030.

Barbosa, A., \& Vale, I. (2015). Visualization in pattern generalization: Potential 
and Challenges. Journal of the European Teacher Education Network, 10(1), 57-70.

Barbosa, A., Value, I., \& Palhares, P. (2009). Exploring generalization with visual petterns: task developed with prealgebra students. Meeting on Patterns, Maio de 2009, Viana Do Castelo, 1-14.

Chua, B., \& Hoyles, C. (2014). Generalisation of linear figural patterns in secondary school mathematics. 15(2), 1-30.

Dundar, S. (2015). An Analysis on the Pattern Generalizations of the Turkish Pre-Service Mathematics Teachers That Are Presented in a Different Structure and Presentation. Educational Research and Reviews, 10(2), 210-224.

Ellis, A. B. (2007). Connections between generalizing and justifying: Students' reasoning with linear relationships. Journal for Research in Mathematics Education, 38(3), 194-229.

Faturohman, I., \& Afriansyah, E. A. (2020). Peningkatan Kemampuan Berpikir Kreatif Matematis Siswa melalui Creative Problem Solving. Mosharafa: Jurnal Pendidikan Matematika, 9(1), 107-118.

Fyfe, E. R., Evans, J. L., Matz, L. E., Hunt, K. M., \& Alibali, M. W. (2017). Relations between patterning skill and differing aspects of early mathematics knowledge. Cognitive Development, 44(May 2016), 1-11.

Girit, D., \& Akyuz, D. (2016). Algebraic Thinking in Middle School Students at Different Grades: Conceptions about Generalization of Patterns. Necatibey Faculty of Education Electronic Journal of Science and Mathematics Education, 10(2), 243-243.

Goldstone, R. L., Marghetis, T., Weitnauer, E., Ottmar, E. R., \& Landy, D. (2017). Adapting Perception, Action, and Technology for Mathematical Reasoning. Current Directions in Psychological Science, 26(5), 434-441. Kieran, C. (2004). Algebraic thinking in the early grades: What is it. The Mathematics Educator, 8(1), 139151.

Kılıç, Ç. (2016). Analyzing Middle School Students' Figural Pattern Generating Strategies Depending on a Linear Number Pattern. 12(6), 1205-1230.

Kılıç, Ç. (2017). The Ability of Pre-Service Primary Teachers to Produce Figural Patterns Based on Algebraic Formulas. Turkish Journal of Computer and Mathematics Education (TURCOMAT), 8(2), 261-261.

Lannin, J. K., Barker, D. D., \& Townsend, B. E. (2006). Algebraic generalisation strategies: Factors influencing student strategy selection. Mathematics Education Research Journal, 18(3), 328.

Lian, L. H., \& Yew, W. T. (2012). Assessing algebraic solving ability: A theoretical framework. International Education Studies, 5(6), 177-188.

Lie, S. Z., Zhi, T., \& Sean, L. (2017). Generalising The Functional Rule For A Figural Quadratic Pattern.

Maryati, I. (2018). Penerapan Model Pembelajaran Berbasis Masalah Pada Materi Pola Bilangan Di Kelas Vii Sekolah Menengah Pertama. Mosharafa: Jurnal Pendidikan Matematika, 7(1), 63-74.

Mulyani, A., Indah, E. K. N., \& Satria, A. P. 
(2018). Analisis Kemampuan Pemahaman Matematis Siswa Smp Pada Materi Bentuk Aljabar. Mosharafa: Jurnal Pendidikan Matematika, 7(2), 251-262.

Nurmawanti, I., Bambang, E. I., \& Sulandra, M. I. (2016). Identifikasi Pola Siswa SMP Berdasarkan Teori Gestalt. Jurnal Pembelajan Matematika, III(2), 154 161.

Papic, M. M., Mulligan, J. T., Highfield, K., McKay-Tempest, J., \& Garrett, D. (2011). Assessing the Development of Preschoolers' Mathematical Patterning. Journal for Research in Mathematics Education, 42(3), 237269.

Radford, L. (2015). Introduction: the Phenomenological, Components of Generalization. 9(3), 129-141.

Ridia, N. S., \& Afriansyah, E. A. (2019). Perbandingan

Kemampuan

Pemahaman Matematis Siswa melalui Auditory Intellectualy Repetition dan Student Teams Achievement Division. Mosharafa: Jurnal Pendidikan Matematika, 8(3), 515-526.

Rivera, F. D. (2018). Pattern generalization processing of elementary students: Cognitive factors affecting the development of exact mathematical structures. Eurasia Journal of Mathematics, Science and Technology Education, 14(9).

Somasundram, P., Akmar, S. N., \& Eu, L. K. (2019). Pattern Generalisation by Year Five Pupils. International Electronic Journal of Mathematics Education, 14(2).

Vale, I., Pimentel, T., Cabrita, I., \& Barbosa, A. (2012). Pattern Problem Solving Tasks As a Mean To Foster Creativity in Mathematics. Proceedings of the 36th
Conference of the International Group for the Psychology of Mathematics Education, 4(1), 171-178.

Warren, Elizabeth; Cooper, T. (2007). Generalising the pattern rule for visual growth patterns: Actions that support 8 year olds' thinking. Educational Stidies in Mathematics, 67(2), 171185.

Warren, E., Miller, J., \& Cooper, T. J. (2013). Exploring Young Student's Functional Thinking. 4, 75-84.

Wilkie, K. J. (2019). Investigating secondary students' generalization, graphing, and construction of figural patterns for making sense of quadratic functions. The Journal of Mathematical Behavior, 54, 100689.

\section{CURRICULUM Vitae Writer}

Iva Nurmawanti, S.Pd., M.Pd.

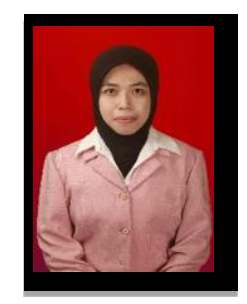

Born in Tulungagung, $14^{\text {th }}$ January 1991. Lecturer in University of Mataram. Degrees of S1 Mathematics Education State University of Malang, 2014; S2 Mathematics Education State University of Malang, 2016.

Dr. rer nat. I Made Sulandra, M.Si.

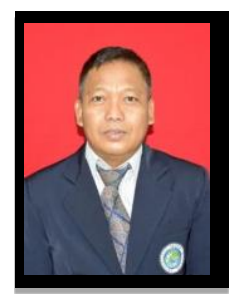

Lecturer in State University of Malang. Degrees of S1 Mathematics Education IKIP Malang, 1986; S2 Mathematics ITB Bandung, 1991, Dr.rer.nat. Mathematics, Universitaet des Saarlandes, Germany, 2003. 